\title{
MICHAŁ ROMANOWSKI
}

PIOTR HAIDUK

https://doi.org/10.33995/wu2021.4.3

\section{Ocena projektu ustawy - o zmianie ustawy - Kodeks spółek handlowych oraz niektórych innych ustaw}

Istota problemu prawnego omawianego w niniejszym artykule sprowadza się do dokonania oceny projektu prawa grup spółek w zwiqzku z projektem ustawy - o zmianie ustawy - Kodeks spółek handlowych oraz niektórych innych ustaw (Druk nr 1515), dalej: projekt lub nowelizacja.

Rozwiqzania zawarte w (nienowym zreszta) projekcie należy ocenić bardzo krytycznie. Stanowiq one w istocie rzeczy zamach na całe prawo spółek i bezpieczeństwo obrotu prawnego, co przekłada się na ryzyko dla polskich i zagranicznych udziałowców spółek, członków zarzqdu i rad nadzorczych spółek.

Słowa kluczowe: grupy spółek, grupy kapitałowe.

\section{Wstęp}

Projektowana nowelizacja rodzi poważne zagrożenie nie tylko dla dużych grup kapitałowych, w tym z udziałem zagranicznego kapitału, i spółek akcyjnych, ale także dla wszystkich spółek kapitałowych w Polsce (blisko 470 tysięcy podmiotów). Nie wymaga szerszego uzasadnienia, że przepisy projektowanej nowelizacji odnoszą się bezpośrednio do grup ubezpieczeniowych.

Zawarte w omawianej nowelizacji regulacje dotyczące grup spółek w fundamentalny sposób zagrożą bezpieczeństwu obrotu. Stanowią one wistocie rzeczy zamach na całe prawo spółek. W praktyce zaś - na polskich i zagranicznych udziałowców spółek, członków zarządu i rad nadzorczych spółek. Proponowane rozwiązania umożliwiają de facto wymuszanie posłuszeństwa biznesu prywatnego, poprzez nadmierny wpływ i na sam biznes prywatny i na członków organizacji spółek sektora prywatnego. Co więcej, skutkiem wejścia w życie projektu może być ustawowe oderwanie 
interesu spółki od interesu akcjonariuszy spółki ${ }^{1}$. W praktyce oznacza to, że o zgodności działań funkcjonariuszy spółki z jej interesem rozstrzygać będą nie akcjonariusze ${ }^{2}$, ale prokurator, a w dalszej kolejności - sądy karne. Dotyczy to wszystkich spółek kapitałowych, nie tylko tych wchodzacych w skład grup kapitałowych. Konsekwencją może być paraliż decyzyjny w spółkach z udziałem Skarbu Państwa i potężne ryzyko prawne w prowadzeniu prywatnego biznesu.

\section{Rzeczywiste problemy funkcjonowania grup kapitałowych w Polsce}

Istota problemów wokół grup kapitałowych (w tym grup kapitałowych w sektorze ubezpieczeniowym) sprowadza się do rozwiązania kilku kwestii. Te problemy to:

1) obawa menedżerów spółek zależnych przed odpowiedzialnością karną z tytułu działania w interesie grupy kapitałowej;

2) ochrona akcjonariuszy mniejszościowych przed nadużyciem prawa większości;

3) ochrona wierzycieli spółki zależnej przed nadużyciem osobowości prawnej spółki.

Polskie prawo spółek pozwala znaleźć obecnie odpowiedź na wszystkie z tych problemów. Z kolei projektowane przepisy ryzyk tych albo w ogóle nie dostrzegaja (kwestia odpowiedzialności karnej członków organów spółek zależnych), albo proponują rozwiązania, które w praktyce pozbawione są znaczenia, a dodatkowo kreują nowe, poważne ryzyka.

\section{System [nie]wiążących poleceń to źródło dalszych problemów, a nie ich rozwiązanie}

Centralnym punktem projektowanych przepisów dot. grup spółek jest system wiążących poleceń

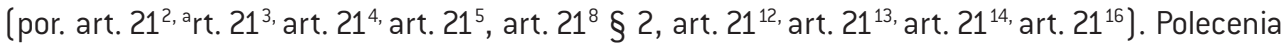
sạ przy tym wiążące jedynie z nazwy ${ }^{3}$.

Koncepcja wiążących poleceń spółki dominującej oznacza, że: (i) zarząd spółki zależnej staje się recenzentem strategii grupy (czytaj: władz spółki matki) oraz stosowanych dla jej wdrożenia narzędzi z obowiązkiem odmowy ich wdrażania ze względu na nadrzędny interes „własnej” spółki ${ }^{4}$.

1. Projektowane art. $21^{1} \S 1$ oraz art. $21^{4} \S 2$ k.s.h. z projektu ustawy - o zmianie ustawy - Kodeks spółek handlowych oraz niektórych innych ustaw (Druk nr 1515).

2. Dla przejrzystości wywodu w artykule stosowana jest terminologia właściwa spółce akcyjnej (w szczególności: akcjonariusze, akcje, walne zgromadzenie), chyba że co innego zostało wskazane wprost lub wynika z kontekstu.

3. Projektowany art. $21^{2} \S 1$ k.s.h. „Spółka dominująca może wydać spółce zależnej uczestniczącej w grupie spółek wiążące polecenie dotyczące prowadzenia spraw spółki (wiążące polecenie), jeżeli jest to uzasadnione interesem grupy spółek oraz jeżeli przepisy szczególne nie stanowią inaczej”. Projekt ustawy - o zmianie ustawy - Kodeks spółek handlowych oraz niektórych innych ustaw (Druk nr 1515).

4. Projektowany art. $21^{3}$ k.s.h. Projekt ustawy - o zmianie ustawy - Kodeks spółek handlowych oraz niektórych innych ustaw (druk nr 1515).

„§1. Wykonanie wiążacego polecenia przez spółkę zależną uczestniczącą w grupie spółek wymaga uprzedniej uchwały zarządu spółki zależnej.

$\S 2$. Uchwała o wykonaniu wiążącego polecenia jest podejmowana, o ile nie wystapiły przesłanki określone w art. $21^{4} \S 1-3$.

$\S 3$. Uchwała zawiera co najmniej elementy treści wiążącego polecenia, o których mowa w art. $21^{2} \S 3$. 
Zarzạd spółki zależnej nie ma jednak kompetencji ani narzędzi, aby dokonywać takiej oceny; (ii) wprowadzenie prawa weta dla zarządu spółki zależnej (recenzowanie poleceń spółki dominującej) ${ }^{5}$, które podważa funkcjonowanie grupy jako całości i sprawczą rolę spółki dominującej; (iii) wysokie ryzyko odpowiedzialności cywilnej i karnej członków zarządu i rady nadzorczej spółki zależnej za wykonywanie poleceń spółki dominujacej ${ }^{6}$. Odmowa wykonania polecenia (czyli zaniechanie) wymaga uprzedniej (!) uchwały zarządu spółki zależnej?

W istocie spółka dominująca i spółka zależna zawierają ze sobą umowę o wykonanie wiążącego polecenia, które nie jest w związku z tym wiążące! Wszak umowa zakłada autonomię woli stron. Zarzạd spółki zależnej będzie mógł bezpiecznie prawnie podjąć uchwałę o wykonaniu wiążącego polecenia, jeżeli będzie miał pewność, że: (i) nie zostanie podważone prawo spółki dominującej

§4. Spółka zależna uczestnicząca w grupie spółek informuje spółkę dominującą o podjęciu uchwały o wykonaniu wiążacego polecenia albo uchwały o odmowie wykonania wiążącego polecenia"] oraz art. $21^{4 \text { k.s.h.: }}$

„§1. Spółka zależna uczestnicząca w grupie spółek podejmuje uchwałę o odmowie wykonania wiążącego polecenia, jeżeli wykonanie polecenia doprowadziłoby do niewypłacalności albo do zagrożenia niewypłacalnością tej spółki.

§2. Spółka zależna uczestnicząca w grupie spółek niebędąca spółką jednoosobową podejmuje uchwałę o odmowie wykonania wiążącego polecenia, jeżeli istnieje uzasadniona obawa, że jest ono sprzeczne z interesem tej spółki i wyrządzi jej szkodę, która nie będzie naprawiona przez spółkę dominującą lub inną spółkę zależną uczestnicząca w grupie spółek w okresie najbliższych dwóch lat, licząc od dnia, w którym nastapi zdarzenie wyrządzające szkodę, chyba że umowa spółki stanowi inaczej. W określeniu wysokości szkody spółka zależna uwzględnia korzyści uzyskane przez tę spółkę w związku z uczestnictwem w grupie spółek w okresie ostatnich dwóch lat obrotowych.

§ 3. Umowa albo statut spółki zależnej uczestniczącej w grupie spółek może przewidywać dodatkowe przesłanki odmowy wykonania wiążącego polecenia.

§4. Skuteczność uchwały o zmianie umowy albo statutu spółki zależnej wprowadzającej postanowienia, o których mowa w $\S 3$, zależy od odkupienia przez spółkę dominująca udziałów albo akcji tych wspólników albo akcjonariuszy spółki zależnej, którzy nie zgadzają się na zmianę. Wspólnicy albo akcjonariusze, obecni na zgromadzeniu wspólników albo na walnym zgromadzeniu, zgłaszają żądanie kupienia ich udziałów albo akcji, w terminie dwóch dni od dnia zakończenia zgromadzenia. Nieobecni wspólnicy zgłaszają żądanie wykupienia ich udziałów w terminie miesiąca od dnia zakończenia zgromadzenia wspólników, na którym podjęto uchwałę o zmianie umowy spółki, a akcjonariusze w terminie miesiąca od dnia ogłoszenia uchwały o zmianie statutu. Wspólników albo akcjonariuszy, którzy nie zgłoszą żądania wykupienia ich udziałów albo akcji w terminie, uważa się za zgadzających się na zmianę. Przepisy art. 417 §1-3 stosuje się odpowiednio.

§5. Odmowa wykonania wiążącego polecenia, o której mowa w $\S 1$ i 2 , wymaga uprzedniej uchwały zarządu spółki zależnej uczestniczącej w grupie spółek. Uchwała zawiera uzasadnienie".

5. Projektowany art. $21^{4}$ k.s.h. (cytowany powyżej).

6. Artykuł $21^{5} \S 1$ k.s.h. „Członek zarządu, rady nadzorczej, komisji rewizyjnej oraz likwidator spółki zależnej nie ponosi odpowiedzialności za szkodę wyrządzoną wykonaniem wiążącego polecenia na podstawie art. 293, art. $300^{125} \mathrm{i}$ art. 483 ”, przy czym przepis ten w ogóle milczy o odpowiedzialności karnej, która ma w praktyce fundamentalne znaczenie.

7. Projektowany art. $21^{4} \S 5$ k.s.h. (cytowany powyżej) stanowi kolejny przykład braku staranności w redagowaniu przepisów. W art. 21 ${ }^{4}$. § 1 najpierw błędnie mowa jest o uchwałach spółek zależnych (co jest oczywiście niepoprawne: uchwały podejmowane są przez organy kolegialne - np. organy spółek, a nie same spółki], a nie zarządów spółek zależnych. Następnie w $§ 5$ mowa jest o tym, że zaniechanie (odmowa wykonania wiążącego polecenia) wymaga uprzedniej uchwały zarządu spółki zależnej. Tymczasem polecenie wiążące pozostaje tak długo niewykonane, aż ktoś go nie wykona. Z istoty rzeczy uchwała w sprawie niewykonania wiążącego polecenia nie będzie mieć charakteru uprzedniego względem jego niewykonania, chyba że zostanie podjęta jednocześnie z otrzymaniem wiążącego polecenia. 
do sprawowania jednolitego kierownictwa nad spółkami zależnymi; (ii) wykonanie wiążącego polecenia jest uzasadnione interesem grupy, który ustalają organy spółki dominującej ${ }^{9}$; (iii) dokonał samodzielnie trafnego oszacowania korzyści lub szkody związanej z wykonaniem polecenia ${ }^{1011}$. Zarząd spółki zależnej musi więc wyrazić zgodę na wyrządzenie szkody spółce, a w konsekwencji (co najmniej pośrednio) jej akcjonariuszom i wierzycielom; (iv) dokonał samodzielnego oszacowania, czy i kiedy wyrządzona szkoda zostanie spółce naprawiona oraz jaka jest szansa egzekucji naprawienia szkody od spółki dominujacej ${ }^{12}$. Uchwała zarządu spółki zależnej w sprawie wykonania wiążącego polecenia będzie podlegać ocenie z punktu widzenia odpowiedzialności cywilnej (art. 293, art. $300^{125}$ i art. 483 k.s.h.) oraz karnej (art. 296 k.k.) za należyte prowadzenie spraw spółki, a tu kryterium nadrzędnym ma być interes spółki zależnej, a nie interes grupy. Jeżeli zarząd spółki zależnej będzie miał wạtpliwości, a powinien mieć, bo nie ma instrumentów i kompetencji, aby bezpiecznie prawnie zrecenzować zarząd spółki dominujacej, to powinien odmówić wykonania wiążącego polecenia. Łatwość stawiania przez prokuraturę zarzutów działania na szkodę spółki jest powszechnie znana. Sądy działają coraz wolnej. Łatwo będzie zatem uderzyć w zarządzającego.

Co więcej, przepis art. $21^{5} \S 1$ k.s.h. wyłączający (pod pewnymi warunkami - o czym szerzej poniżej] odpowiedzialność funkcjonariuszy spółki zależnej za działanie w interesie grupy spółek dotyczy jedynie odpowiedzialności odszkodowawczej, i to wobec samej spółki. W praktyce tego rodzaju odpowiedzialność jest zarządzalna i ma marginalne znaczenie. Istota problemu jest odpowiedzialność karna, a tej projektowane przepisy w ogóle nie adresuja.

Niezależnie od powyższego, przewidywane w projekcie zwolnienie z odpowiedzialności cywilnej członków zarządu spółki zależnej za wykonanie wiążącego polecenia zakłada nie tylko, że ocena zarządu spółki zależnej prawa spółki dominujaccej do wydania polecenia i ocena owego polecenia i jego skutków była uzasadniona, ale przede wszystkim to, że takie wiążące polecenie w ogóle zostanie wydane.

Tymczasem to, co jakoś wyglada na papierze (w tym przypadku trudno powiedzieć, aby wyglądało dobrze], może zupełnie inaczej wyglądać w praktyce. Przykładem może być słynny art. ? prawa o prokuraturze ${ }^{13}$ i możliwość żądania przez prokuratora polecenia na piśmie. Wystarczy zapytać prokuratorów, ile ostatnio dostali poleceń na piśmie. Należy zastanowić się, kiedy faktycznie powstanie konieczność wydania wiążącego polecenia przez spółkę dominującą. Modelowo dotyczyć to będzie sytuacji budzących wątpliwości - przede wszystkim zarządów spółek zależnych. Powstaje jednak pytanie o perspektywę spółki dominującej: z czym wiąże się wydanie wiążącego polecenia?

W tym miejscu ujawnia się kwestia braku realnego zaadresowania w projekcie pozostałych problemów funkcjonowania grup kapitałowych (zob. pkt 1). Z uwagi na ramy artykułu w tym miejscu można ograniczyć się do stwierdzenia, że warunkiem odpowiedzialności spółki dominującej wobec

8. Projektowany art. 4 w $\S 1$ pkt $5^{1}$ k.s.h. (cytowany powyżej); „grupa spółek - spółkę dominującą i spółkę lub spółki od niej zależne, kierujace się wspólną strategia gospodarczą w celu realizacji wspólnego interesu, uzasadniająca sprawowanie przez spółkę dominująca jednolitego kierownictwa nad spółką zależną albo spółkami zależnymi”.

9. Projektowany art. $21^{2} \S 1$ k.s.h. (cytowany powyżej).

10. Projektowany art. $21^{4} \S 1$ i 2 k.s.h. (cytowany powyżej).

11. M. Chomiuk, R. Harnos, Uwagi prawno-porównawcze z perspektywy prawa niemieckiego do projektu prawa grup spółek, „Monitor Prawa Handlowego” 2021, nr 1, s. 10.

12. Projektowany art. $21^{4} \S 1$ i 2 k.s.h. (cytowany powyżej).

13. Ustawa z 28 stycznia 2016 r. - Prawo o prokuraturze (tekst jedn. Dz. U. 2021, poz. 66, z późn. zm.]. 
akcjonariuszy spółek zależnych oraz wierzycieli tych spółek jest to, że źródłem szkody musi być wiążące polecenie (art. $21^{13} \S 1$ k.s.h. ${ }^{14}$ oraz art. $21^{14} \S 1$ k.s.h. ${ }^{15}$ ]. ${ }^{16}$ Jeżeli wiążącego polecenia (w rozumieniu art. $21^{2}$ k.s.h.] nie będzie, roszczenia odszkodowawcze względem spółki dominującej nie przysługuja. ${ }^{17}$ Wydając wiążące polecenie, spółka dominująca naraża się natomiast na potencjalną odpowiedzialność cywilną, a jej członkowie zarządu - na cywilną i karną. Jeżeli dodać do tego zbiurokratyzowany sposób wydawania wiążących poleceń ${ }^{18}$ oraz ich przyjmowania do wykonania ${ }^{19}$, nie potrzeba szczególnej wyobraźni, aby dostrzec, że w praktyce spółki dominujące nie będą chętne, aby z tego instrumentu w ogóle korzystać. Funkcjonowanie grup kapitałowych zejdzie zatem do strefy szarości, w której faktyczne polecenia będą wydawane poza reżimem prawnym współpracy w ramach grupy kapitałowej. To istotny regres w stosunku do braku jakiejkolwiek regulacji, która pozwalała na elastyczne ułożenie tej kwestii. W zależności od pozycji prawnej i faktycznej członków zarzadów spółek zależnych albo przyjmą oni ryzyko wykonania takiego faktycznego polecenia, albo zostaną odwołani przez spółkę matkę, albo - jeżeli korzystają z politycznej protekcji - nie zrobią nic.

W konsekwencji projekt nie adresuje we właściwy sposób żadnego z istotnych zagadnień dotyczących funkcjonowania grup kapitałowych:

1) nie chroni on menedżerów spółek zależnych przed odpowiedzialnością karną z tytułu działania w interesie grupy kapitałowej - przeciwnie: istotnie zwiększa takie ryzyko;

2) nie chroni on akcjonariuszy mniejszościowych przed nadużyciem prawa większości - przeciwnie: iluzoryczny system odpowiedzialności spółki dominujaccej będzie jedynie utrudniał dochodzenie roszczeń przez akcjonariuszy spółki zależnej;

3) nie chroni on wierzycieli spółki zależnej przed nadużyciem osobowości prawnej spółki20 - podobnie jak w przypadku ochrony akcjonariuszy mniejszościowych przewidziane instrumenty jedynie zaciemniają obraz sytuacji.

14. Projektowany art. $21^{13} \S 1$ k.s.h. Projekt ustawy - o zmianie ustawy - Kodeks spółek handlowych oraz niektórych innych ustaw (druk nr 1515). „Spółka dominująca, która na dzień wydania wiążącego polecenia spółce zależnej uczestniczącej w grupie spółek dysponuje, bezpośrednio bądź pośrednio, większością głosów umożliwiającą podjęcie uchwały o uczestnictwie w grupie spółek oraz o zmianie umowy albo statutu spółki zależnej, odpowiada wobec wspólnika albo akcjonariusza tej spółki za obniżenie wartości przysługującego mu udziału albo akcji, jeżeli obniżenie było nastẹpstwem wykonania przez spółkę zależną wiążącego polecenia”.

15. Projektowany art. $21^{14} \S 1$ k.s.h. (cytowany powyżej). „Jeżeli egzekucja przeciwko spółce zależnej uczestniczącej w grupie spółek okaże się bezskuteczna, spółka dominująca odpowiada za szkodę wyrządzoną wierzycielowi spółki zależnej, chyba że nie ponosi winy lub szkoda nie powstała w następstwie wykonania przez spółkę zależna wiążacego polecenia. Przepis art. $21^{12} \S 3$ stosuje się odpowiednio".

16. B. Sołtys, Kilka uwag i propozycji do kodeksowej regulacji nowego prawa holdingowego, „Przegląd Prawa Handlowego" 2021, nr 1, s. 5-16.

17. Por. Opinia Rady Legislacyjnej przy Prezesie Rady Ministrów z 16 października 2020 r. o projekcie ustawy o zmianie ustawy - Kodeks spółek handlowych oraz niektórych innych ustaw ( $\mathrm{Nr}$ RL-033-28/20).

18. Projektowany art. $21^{2}$ k.s.h. (cytowany powyżej).

19. Projektowany art. $21^{3}$ k.s.h. oraz art. $21^{4}$ k.s.h. (cytowane powyżej).

20. Szerzej o tzw. odpowiedzialności przebijającej zob.: A. Opalski i A.W. Wiśniewski, którzy wskazują, że „Bodaj najbardziej typowym przejawem »nadużycia formy prawnej spółki« jest wykorzystanie »zasłony korporacyjnej《 spółek kapitałowych do zwolnienia się przez jej wspólników od następstw działań z pokrzywdzeniem wierzycieli. Istotna rola przypada dlatego zagadnieniu dopuszczalności pociągnięcia wspólnika do osobistej odpowiedzialności za zobowiązania spółki, czyli odpowiedzialności przebijającej. [...] Przeciwko wspólnikowi, który nadużywa instrumentów wpływu na spółkę zależną, dopuszcza do jej niedokapitalizowania czy pomieszania sfer bądź majątków mogą być kierowane roszczenia odszkodowawcze. [...] Roszczenia wierzycieli mają charakter deliktowy 
Powstaje zatem pytanie, czy paradoksalnie projekt prawa grup spółek nie stwarza przestrzeni dla usamodzielniania się i uniezależniania spółek zależnych w ramach grupy spółek, co może sprzyjać zjawiskom nepotyzmu w spółkach z udziałem Skarbu Państwa? Może to także doprowadzić do wymuszania określonych zachowań bez odpowiedzialności prawnej i w konsekwencji ułatwiać budowanie spółki zależnej jako sfery wpływu politycznego. Zarządzanie spółkami zależnymi przez podmioty z udziałem Skarbu Państwa będzie bowiem w praktyce zależeć nie od kwestii merytorycznych, ale od tego, kto ma jakie poparcie polityczne. Niezależnie od tego, jaki jest cel projektodawców, minister aktywów państwowych nie wziął pod uwagę, że przy okazji istotnie zmieni stosunki wewnętrzne w spółkach prywatnych. To jest kontekst, którego warto poszukać. Projekt w istocie stanowi atak na spółki kapitałowe - zarówno stricte prywatne jak i te z udziałem Skarbu Państwa. ${ }^{21}$

Jedynie na marginesie można wskazać, że projekt w ogóle nie analizuje funkcjonowania konglomeratów finansowych i obowiązków z tym związanych w rozumieniu ustawy o nadzorze uzupełniającym nad instytucjami kredytowymi, zakładami ubezpieczeń, zakładami reasekuracji i firmami inwestycyjnymi wchodzącymi w skład konglomeratu finansowego ${ }^{22}$. W tym miejscu można ograniczyć się do stwierdzenia, że projektowane regulacje w zasadzie uniemożliwiają prawidłową realizację podmiotu wiodącego w konglomeracie (PZU S.A.), a tym samym stoją w sprzeczności z przepisami dyrektywy 2002/87/WE ${ }^{23}$.

(art. 415, 422 k.c.). Pozwalają one na swoiste »pominięcie« spółki jako ogniwa pośredniego między wspólnikiem a wierzycielem, instrumentalnie wykorzystywanego przez wspólnika na szkodę wierzycieli [...]"- A. Opalski, A.W. Wiśniewski, [w:] Kodeks spółek handlowych. Tom III A. Spółka akcyjna. Komentarz do art. 301-392, [red.] A. Opalski, Warszawa 2016, Komentarz do art. 1 k.s.h., Legalis. Podobnie również S. Sołtysiński: „Instytucja »nadużycia formy (instytucji) prawnej spółki« obejmuje najczęściej sytuacje, gdy odrębna podmiotowość prawna jest wykorzystywana przez akcjonariuszy lub założycieli do obejścia zakazów ustawowych, uniknięcia lub ograniczenia odpowiedzialności przez akcjonariusza w sposób sprzeczny z prawem, zasadami współżycia społecznego lub społeczno-gospodarczym przeznaczeniem spółki akcyjnej. Sankcje polegają tu najczęściej na pozbawieniu osób »stojących za spółką korzyści związanych z wyłączeniem ich odpowiedzialności za zobowiązania spółki (art. 301 $\S 5$ KSH]", S. Sołtysiński, [w:] Kodeks Spółek Handlowych, t. Ill. Komentarz do art. 301-458, [red.] S. Sołtysiński, A. Szajkowski, A. Szumański, CH Beck, Warszawa 2003, s. 26; A. Szumański, [w:] System Prawa Prywatnego. Tom 17a, [red.] S. Sołtysiński, CH Beck, Warszawa 2010. s. 729-732; M. Litwińska-Werner, Nadużycie formy spółki, „Studia Prawa Prywatnego" 2007, nr 3. Ponadto doktryna piercing the corporate veil najbardziej rozwinięta jest w Stanach Zjednoczonych i stanowi jedną z najczęstszych podstaw sporów korporacyjnych w tym kraju. Rozwiązania wypracowane przez sądy w USA stanowią naturalny punkt odniesienia dla jej zastosowania w innych systemach prawnych, w tym także w polskim. Zasada „czynienia sprawiedliwości” (doing justice) i zapobieganie „oszustwom i bezprawności” (preventing farud and unfairness) stanowią warunek sine qua non każdorazowego nieuwzględnienia odrębnej podmiotowości prawnej spółki, zob. R.B. Thompson, The Limits of Liability in the New Limited Liability Entities, „Wake Forest Law Review” 1997, Vol. 32, No. 3, s. 1, oraz B. Jankowski, Nadużycie formy prawnej spółki w prawie amerykańskim, „Państwo i Prawo” 1996, nr 2, s. 70.

21. Por. A. Opalski, Projekt prawa grup spółek, czyli skok na spółki Skarbu Państwa, „Rzeczpospolita” 23.08.2020, https://www.rp.pl/Rzecz-o-prawie/308189988-Adam-Opalski-Projekt-prawa-grupspolek-czyli-skok-na-spolki-Skarbu-Panstwa.html [dostęp: 18.12.2021].

22. Ustawa z dnia 15 kwietnia 2005 r. o nadzorze uzupełniającym nad instytucjami kredytowymi, zakładami ubezpieczeń, zakładami reasekuracji i firmami inwestycyjnymi wchodzącymi w skład konglomeratu finansowego (tekst jedn. Dz. U. 2019, poz. 2146 z późn. zm.).

23. Dyrektywa 2002/87/WE Parlamentu Europejskiego i Rady z dnia 16 grudnia 2002 r. w sprawie dodatkowego nadzoru nad instytucjami kredytowymi, zakładami ubezpieczeń oraz przedsiębiorstwami inwestycyjnymi konglomeratu finansowego i zmieniająca dyrektywy Rady 73/239/EWG, 79/267/EWG, 92/49/EWG, 92/96/ EWG, 93/6/EWG i 93/22/EWG oraz dyrektywy 98/78/WE i 2000/12/WE Parlamentu Europejskiego i Rady. 


\section{Droga do wywłaszczenia akcjonariuszy mniejszościowych}

Niejako przy okazji zmian dotyczących grup spółek projektowane przepisy radykalnie zmieniaja zasady przymusowego wykupu akcji, rozszerzając je na spółki z ograniczoną odpowiedzialnością (projektowany art. $21^{11} \S 1$ k.s.h. ${ }^{24}$ ).

Co więcej, obok obniżenia progu udziału w spółce zależnej wymaganego do podjęcia takiej uchwały (z 95\% do 90\%) w paragrafie drugim projektowanego przepisu, otwarta została furtka do dalszego zmniejszenia tego progu do poziomu $75 \%{ }^{25}$. Uwzględniając przy tym, że uczestnictwo w grupie spółek ma także wymagać większości 75\% głosów ${ }^{26}$, oraz to, że do zmiany statutu wymagana większość również wynosi 75\% głosów, należy uznać, iż otwiera to drogę do przymusowego wykupu wszystkich akcjonariuszy posiadających mniej niż $25 \%$ akcji w spółkach kapitałowych. Żadnej ochrony akcjonariuszy mniejszościowych nie zapewnia odpowiednie stosowanie projektowanego art. $21^{4} \S 4$ k.s.h. ${ }^{27,28}$. Przeciwnie: osłabia on w istocie rzeczy pozycję akcjonariuszy mniejszościowych. ${ }^{29}$ Abstrahując nawet od kuriozalnie krótkich terminów na zgłoszenie sprzeciwu przez akcjonariuszy mniejszościowych na zmianę statutu ( 2 dni dla akcjonariuszy obecnych na walnym zgromadzeniu], nie sposób zrozumieć, co kierowało projektodawcami. Zamierzają oni bowiem chronić akcjonariuszy mniejszościowych przed zmianą statutu ułatwiającą ich przymusowy wykup poprzez wprowadzenie możliwości żądania przez nich odkupienia ich akcji, co stanowi kuriozum!

Co więcej, w praktyce może okazać się, że wystarczy utworzyć grupę dwóch spółek, aby skorzystać z opcji przymusowego wykupienia akcjonariusza (wspólnika) posiadającego mniej niż 25\% kapitału zakładowego oraz głosów w spółce.

24. Projektowany art. $21^{11} \S 1$ k.s.h. Projekt ustawy - o zmianie ustawy - Kodeks spółek handlowych oraz niektórych innych ustaw (Druk nr 1515). „Zgromadzenie wspólników albo walne zgromadzenie spółki zależnej uczestniczącej w grupie spółek może podjąć uchwałę o przymusowym wykupie udziałów albo akcji wspólników albo akcjonariuszy reprezentujących nie więcej niż 10\% kapitału zakładowego przez spółkę dominująca, która reprezentuje bezpośrednio co najmniej 90\% kapitału zakładowego. Przepisy art. 417 §1-3 oraz art. 418 $\S 2$, 2 b i 3 zdanie drugie i trzecie stosuje się odpowiednio".

25. Projektowany art. $21^{11} \S 2$ k.s.h. (cytowany powyżej). „Umowa albo statut spółki zależnej może przewidywać, że uprawnienie, o którym mowa w $\S 1$, przysługuje spółce dominującej, która bezpośrednio lub pośrednio reprezentuje w spółce zależnej uczestniczącej w grupie spółek mniej niż 90\% kapitału zakładowego takiej spółki, lecz nie mniej niż 75\% tego kapitału. Przepis art. $21^{4}$ § 4 stosuje się".

26. Projektowany art. $21^{1} \S 2$ k.s.h. (cytowany powyżej).

27. Zgodnie z projektowanym przepisem art. $21^{4} \S 4$ k.s.h. (cytowany powyżej). „Skuteczność uchwały o zmianie umowy albo statutu spółki zależnej wprowadzającej postanowienia, o których mowa w § 3, zależy od odkupienia przez spółkę dominującą udziałów albo akcji tych wspólników, albo akcjonariuszy spółki zależnej, którzy nie zgadzają się na zmianę. Wspólnicy albo akcjonariusze, obecni na zgromadzeniu wspólników albo na walnym zgromadzeniu, zgłaszają żądanie kupienia ich udziałów albo akcji, w terminie dwóch dni od dnia zakończenia zgromadzenia. Nieobecni wspólnicy zgłaszają żądanie wykupienia ich udziałów w terminie miesiąca od dnia zakończenia zgromadzenia wspólników, na którym podjęto uchwałę o zmianie umowy spółki, a akcjonariusze w terminie miesiąca od dnia ogłoszenia uchwały o zmianie statutu. Wspólników albo akcjonariuszy, którzy nie zgłoszą żądania wykupienia ich udziałów albo akcji w terminie, uważa się za zgadzających się na zmianę. Przepisy art. 417 § 1-3 stosuje się odpowiednio".

28. Por. A. Opalski, op. cit.

29. B. Sołtys, op. cit. 
Kwestia instytucji przymusowego wykupu akcjonariuszy mniejszościowych była już przedmiotem badania pod kątem zgodności z Konstytucją ${ }^{30}$. Dopuszczając taką możliwość przy progu 95\%, Trybunał Konstytucyjny stwierdził, że „[e]ksperci Komisji Europejskiej sugerują dwa kryteria stosowania instytucji »wyciśnięcia《 w prawodawstwach państw członkowskich: osiagnięcie przez akcjonariuszy progu 90-95\% udziałów w spółce oraz stosowną rekompensatę (raport specjalnej grupy ekspertów Komisji Europejskiej - Report of the High Level Group of Company Law Experts on a Modern Regulatory Framework for Company Law in Europe, 4 listopada 2002 r.).

Jak już zostało to wskazane powyżej, w sytuacji kolizji praw należy gwarantować, by prawodawca nie przekraczał dopuszczalnego zakresu odstępstw od stanu optymalnej ochrony wszystkich kolidujących ze sobą wartości. Interes spółki akcyjnej (utożsamiany z interesem wspólników większościowych), prawo spółki do rozwoju i prowadzenia efektywnej działalności gospodarczej jest tu wartością przeciwstawianą prawu majątkowemu akcjonariuszy mniejszościowych do akcji” ${ }^{31}$.

Ponad 20-procentowy udział w spółce kapitałowej jest już udziałem znacznym, którego nie można pomijać przy ustalaniu interesu takiej spółki. Wiążą się z nim także istotne uprawnienia korporacyjne (np. możliwość wyboru członków rady nadzorczej grupami). W tym kontekście dopuszczenie do obniżenia progu przymusowego wykupu do poziomu $75 \%$ udziału w kapitale spółki zależnej wydaje się wręcz w oczywisty sposób niekonstytucyjne.

\section{Podsumowanie}

Biorąc pod uwagę powyższe, można ograniczyć się do stwierdzenia, że podstawową wadą regulacji jest brak przemyślenia przez projektodawców negatywnych konsekwencji, jakie wywrze ona na stosowanie prawa oraz praktykę biznesową w Polsce. Oznaczać to będzie trudne nawet do przewidzenia zagrożenie dla prowadzenia działalności gospodarczej w Polsce.

W przypadku spółek z udziałem Skarbu Państwa należy spodziewać się jeszcze większego paraliżu decyzyjnego niż dotychczas. Z kolei z perspektywy spółek prywatnych otwiera się przestrzeń do oceny decyzji biznesowych przez prokuraturę nawet wtedy, gdy nikt nie został poszkodowany (art. 296 § 1a Kodeksu karnego).

Ponadto przepisy projektowanej nowelizacji prowadzą do uniemożliwienia prawidłowej realizacji obowiązków podmiotu wiodącego w konglomeracie finansowym (w Polsce jest to PZU S.A.) i stoją tym samym w sprzeczności z przepisami dyrektywy 2002/87/WE.

\section{Wykaz źródeł}

Chomiuk M., Harnos R., Uwagi prawno-porównawcze z perspektywy prawa niemieckiego do projektu prawa grup spółek, „Monitor Prawa Handlowego” 2021, nr 1.

Jankowski B., Nadużycie formy prawnej spółki w prawie amerykańskim, „Państwo i Prawo” 1996, nr 2. Litwińska-Werner M., Nadużycie formy spółki, „Studia Prawa Prywatnego” 2007, nr 3.

30. Zamiast wielu zob. W. Popiołek, Komentarz do art. 418 k.s.h., nb. 3, [w:] Kodeks spółek handlowych. Komentarz, [red.] J. Strzępka, Warszawa 2015, Legalis 2021.

31. Wyrok Trybunału Konstytucyjnego z 21 czerwca 2005 r., sygn. P 25/02. 
Opalski A. Projekt prawa grup spółek, czyli skok na spółki Skarbu Państwa, „Rzeczpospolita” 23.08.2020.

Opalski A., Wiśniewski A.W., [w:] Kodeks spółek handlowych. Tom III A. Spółka akcyjna. Komentarz do art. 301-392, Opalski A. [red.], CH Beck, Warszawa 2016.

Opinia Rady Legislacyjnej przy Prezesie Rady Ministrów z 16 października 2020 r. o projekcie ustawy o zmianie ustawy - Kodeks spółek handlowych oraz niektórych innych ustaw ( $\mathrm{Nr}$ RL-033-28/20).

Popiołek W., [w:] Kodeks spółek handlowych. Komentarz, Strzępka J. [red.], Warszawa 2015, Legalis 2021.

Sołtys B., Kilka uwag i propozycji do kodeksowej regulacji nowego prawa holdingowego, „Przegląd Prawa Handlowego" 2021, nr 1.

Sołtysiński S., [w:] Kodeks Spółek Handlowych, t. III. Komentarz do art. 301-458, Sołtysiński S., Szajkowski A., Szumański A. [red.], CH Beck, Warszawa 2003.

Szumański A., [w:] System Prawa Prywatnego. Tom 17a, Sołtysiński S. [red.], CH Beck, Warszawa 2010. Thompson R.B., The Limits of Liability in the New Limited Liability Entities, "Wake Forest Law Review" 1997, Vol. 32, No. 3.

\section{Evaluation of the draft of the bill amending the Code of Commercial Companies and certain other acts}

The essence of the legal problem discussed in this article boils down to the evaluation of the project of corporate groups law in connection with the draft of the bill amending the Code of Commercial Companies and certain other acts (Journal of Laws no 1515). The solutions contained in the (by the way, not new) draft should be assessed very critically. In fact, they constitute an attack on the entire corporate law and security of legal transactions, which corresponds to a risk for Polish and foreign shareholders of companies, members of management boards and supervisory boards of companies.

Keywords: corporate groups, capital groups.

PROF. DR HAB. MICHAL ROMANOWSKI - profesor prawa w Katedrze Prawa Handlowego na WPiA Uniwersytetu Warszawskiego; adwokat i partner w kancelarii Romanowski i Wspólnicy ORCID: 0000-0003-1065-0958

e-mail: m.romanowski@romanowski.eu

PIOTR HAIDUK - adwokat i partner w kancelarii Romanowski i Wspólnicy e-mail:p.haiduk@romanowski.eu 
